\title{
Teknik Menyajikan Data Sentimen Analisis Pada Domain Perguruan Tinggi
}

\author{
Alkautsar Rahman ${ }^{1}$, Yusrila Yeka Kerlooza ${ }^{2}$ \\ Program Pascasarjana, Program Studi Magister Sistem Informasi UNIKOM \\ Jl. Dipati Ukur No. 112-116, Bandung, Jawa Barat, Indonesia
}

alkautsar.r@email.unikom.ac.id

\begin{abstract}
Abstrak - Dalam penyebaran informasi Media Sosial, Website Organisasi, Aplikasi Organisasi mampu memberikan opini / komentar akan tetapi hasil opini / komentar tersebut tidak tersampaikan sesuai dengan kebutuhan informasi yang dibutuhkan oleh setiap hirarki atau struktur organisasi yang ada didalam domain perguruan tinggi. Beberapa metode analisis segmentasi Piramida Hirarki, Piramida Sistem Informasi telah ada sebelumnya dan telah diterapkan di berbagai bidang ilmu. Untuk kasus analisis segmentasi struktur organisasi di UNIKOM ini akan digunakan metode piramida Hirarki, analisa kebutuhan informasi dan penyajian informasi menggunakan metode Piramida Sistem Informasi dan Cognitive Load. Dengan demikian, peneliti akan mengetahui kepentingan, keperluan dan kebutuhan informasi dari setiap jenjang akan mengetahui jenis informasi tertentu, dan batasan informasi yang akan disajikan. Setelah menggunakan metode Piramida Hirarki, Piramida Sistem Informasi dan Cognitive Load untuk segmentasi dan penyajian informasi, setiap jenjang pada struktur organisasi UNIKOM akan mendapatkan informasi dengan konteks dan jumlah yang sesuai.
\end{abstract}

Kata kunci : Piramida Hirarki, Piramida Sistem Informasi, Cognitive Load, Segmentasi, Penyajian informasi.

\begin{abstract}
In presenting information Social Media, Website Organization, Organization Application able to give opinion / comment but the results of opinion / comment was not delivered in accordance with the needs of the information required by any hierarchy or organizational structures that exist within the college domain. Several methods of segmentation analysis Hierarchy Pyramid, Pyramid Information Systems have been there before and have been applied in various fields of science. For the case of segmentation analysis in UNIKOM's organizational structure will be used method hierarchy pyramid, needs analysis information and presentation of information using methods Pyramid Information Systems and Cognitive Load. Thus, researchers will know the interests, needs and requirements of each level will get to know certain types of information, and limit the information to be presented. After using Hierarchy Pyramid, Pyramid of Information Systems and Cognitive Load for segmentation and presentation of information, every level of the organizational structure of UNIKOM will get information about the context and the appropriate amount.
\end{abstract}

Keywords : The hierarchy pyramid, the Pyramid of Information Systems, Cognitive Load, Segmentation, Presentation of information.

\section{Pendahuluan}

Berbagai media dapat digunakan dalam menyebarkan informasi, seperti media sosial, website resmi perusahaan, aplikasi. Media tersebut mampu memberikan sentimen positif dan negatif akan tetapi hasil sentimen tersebut tidak terdistribusi sesuai dengan kebutuhan informasi yang dibutuhkan oleh setiap hirarki atau struktur organisasi yang ada di dalam domain perguruan tinggi, dengan menganalisa kebutuhan informasi dan memetakan hirarki di dalam perguruan tinggi maka segmentasi informasi akan tepat sasaran. Dalam penelitian ini segmentasi informasi akan dilakukan dengan menentukan hirarki yang mengacu kepada hirarki sistem informasi dan melihat kebutuhan hirarki yang ada di dalam domain perguruan tinggi sesuai dengan piramida hirarki.

\section{Metodologi Penelitian}

Untuk mengetahui kebutuhan informasi di dalam hirarki domain perguruan tinggi dapat dilakukan dengan menganalisa kebutuhan menggunakan piramida hirarki.

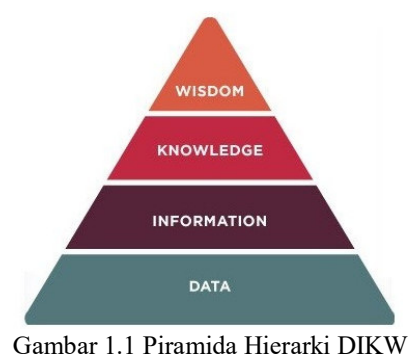

Data : menandai sebagai karakteristik data tidak digunakan sebagai "know-nothing" [3]

Information : informasi sebagai data yang terstruktur diproses sedemikian rupa sehingga informasinya memiliki relevansi untuk tujuan atau konteks tertentu karena bermakna, berharga, berguna dan relevan [5]

Knowledge: pengetahuan sifatnya subyektif bukan universal maupun subyek penelitian ilmu informasi meskipun sering didefinisikan dalam istilah proporsioan [4]

Wisdom : kebijaksanaan sebagai pemahaman yang dievaluasi dimana pemahaman mengemukakan diskrit pengetahuan dan kebijaksanaan [6]. Kebijaksanaan adalah 
kemampuan meningkatkan efektivitas menambah nilai . Menggambarkan kebijaksanaan hanya sebagai informasi pengetahuan tersusun yang dibuat sangat berguna [7].

Dengan mengetahui karakteristik ini, diharapkan informasi yang dihasilkan dapat benar-benar relevan dan memiliki nilai (value) tinggi, sehingga dapat dipergunakan oleh manajemen organisasi dalam menjalankan aktivitas bisnisnya sehari-hari.

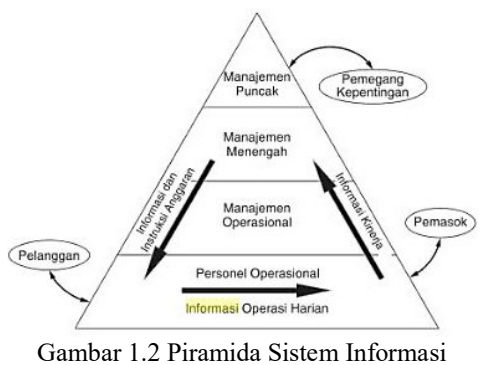

Piramida perusahaan membagi manajemen pengambil keputusan menjadi tiga tingkatan: top manager (TM), middle manager (MM), dan lower manager (LM). Sebagai tingkatan tertinggi, jenis pengambilan keputusan yang dilakukan oleh seorang TM biasanya yang bersifat strategis, dalam arti kata untuk keperluan perencanaan jangka panjang dan penentuan target-target perusahan yang harus dicapai beserta metodenya [8].

Pengetahuan tentang bagaimana manusia belajar, berpikir, dan memecahkan masalah berhubungan dengan arsitektur kognitif manusia. Sweller menyebutkan "Cognitive Load Theory (CLT) began as an instructional theory based on our knowledge of human cognitive architecture" . Arsitektur kognitif ini mengacu pada struktur memori manusia yang terdiri atas memori penginderaan, memori pekerja, dan memori jangka panjang dalam usaha untuk mengolah dan menyimpan informasi [17]

\section{HASIL DAN PEMBAHASAN}

\section{A. Data Segmentasi}

Studi kasus yang diambil untuk segmentasi ini menggunakan struktur organisasi Universitas Komputer (UNIKOM).

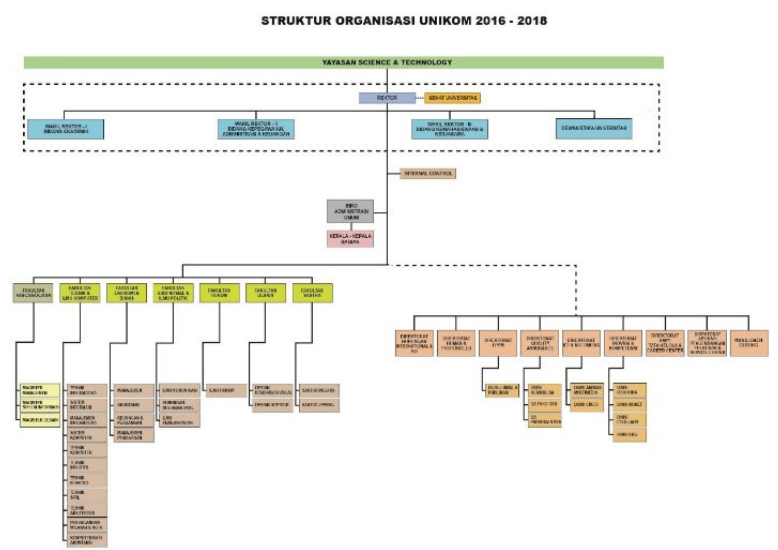

Gambar 1.3 Struktur Organisasi UNIKOM
Sentimen Analisis yang dihasilkan dari media sosial, website dan aplikasi UNIKOM akan dikelompokan berdasarkan fasilitas umum, akademik, dan proses belajar mengajar. Di dalam kelompok - kelompok fasilitas umum dan Fasilitasakademik akan disegmentasikan kepada divisi atau direktorat - direktorat terkait, di dalam proses belajar mengajar akan disegmentasikan kepada setiap dosen terkait.

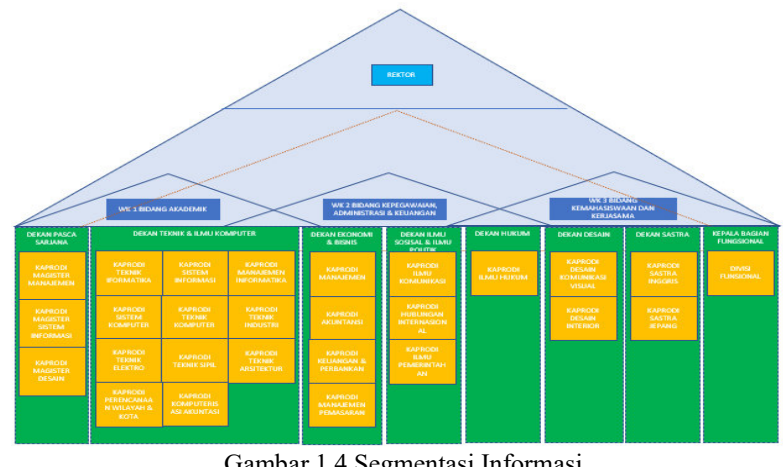

Civitas akademika diharuskan login untuk menggunakan fasilitas umpan balik dan untuk masyarakat umum tidak diperlukan login, hal ini berguna untuk menentukan arah peruntukan segementasi data. Di dalam segmentasi ini setiap jenjang dapat berkomentar sesuai dengan bagianya, komentarkomentar tersebut dikelompokan berdasarkan fasilitas umum, fasilitas akademik, proses belajar dan mengajar.

TABEL I

DATA FASILITAS UMUM

\begin{tabular}{|c|c|c|c|}
\hline Kelompok & Fasilitas & Atribut & Sentimen \\
\hline \multirow{7}{*}{$\begin{array}{l}\text { Fasilitas } \\
\text { Umum }\end{array}$} & Toilet & Lokasi, Lantai, Waktu & Positif \& Negatif \\
\hline & Mushola & $\begin{array}{l}\text { Nama Mushola, Lokasi, } \\
\text { Waktu }\end{array}$ & Positif \& Negatif \\
\hline & Parkir & Lokasi, Lantai, Waktu & Positif \& Negatif \\
\hline & Kantin & Lokasi, Waktu & Positif \& Negatif \\
\hline & $\begin{array}{l}\text { Tempat } \\
\text { Sampah }\end{array}$ & Lokasi, Lantai, Waktu & Positif \& Negatif \\
\hline & Lift & Lokasi, Waktu & Positif \& Negatif \\
\hline & Ruang Rapat & Lokasi, Lantai, Waktu & Positif \& Negatif \\
\hline
\end{tabular}

Fasilitas Umum dapat dikomentari oleh civitas akademika dengan cara login, komentar - komentar terkait Fasilitas Umum akan diterima oleh bagian Manajemen Gedung

TABEL II

DATA FASILITAS AKADEMIK

\begin{tabular}{|c|c|c|c|}
\hline Kelompok & Fasilitas & Atribut & Sentimen \\
\hline \multirow{3}{*}{$\begin{array}{c}\text { Fasilitas } \\
\text { Akademik }\end{array}$} & Ruang Kelas & $\begin{array}{c}\text { Lokasi, Lantai, } \\
\text { Waktu }\end{array}$ & Positif \& Negatif \\
\cline { 2 - 4 } & Laboratorium & $\begin{array}{c}\text { Nama Lab, Lokasi, } \\
\text { Lantai, Waktu }\end{array}$ & Positif \& Negatif \\
\cline { 2 - 4 } & Perpustakaan & $\begin{array}{c}\text { Lokasi, Lantai, } \\
\text { Waktu }\end{array}$ & Positif \& Negatif \\
\cline { 2 - 4 } & $\begin{array}{c}\text { LCD } \\
\text { Proyektor }\end{array}$ & $\begin{array}{c}\text { Lokasi, Lantai, } \\
\text { Waktu }\end{array}$ & Positif \& Negatif \\
\hline
\end{tabular}




\begin{tabular}{|c|c|c|c|}
\hline & $\begin{array}{c}\text { Meja dan } \\
\text { Kursi }\end{array}$ & $\begin{array}{c}\text { Lokasi, Lantai, } \\
\text { Waktu }\end{array}$ & Positif \& Negatif \\
\cline { 2 - 4 } & Komputer & $\begin{array}{c}\text { Lokasi, Lantai, } \\
\text { Waktu }\end{array}$ & Positif \& Negatif \\
\hline
\end{tabular}

Fasilitas Akademik dapat dikomentari oleh civitas akademika dengan cara login, komentar - komentar terkait Fasilitas Akademik akan diterima oleh Bagian Perlengkapan.

TABEL III

Data Proses Belajar dan MENGajar

\begin{tabular}{|c|c|c|c|}
\hline Kelompok & Komentar & Ditujukan & Sentimen \\
\hline $\begin{array}{c}\text { Belajar } \\
\text { dan } \\
\text { Mengajar }\end{array}$ & Komentar - komentar & Dosen terkait & Positif \& Negatif \\
\hline
\end{tabular}

UNIKOM mempunyai sistem umpan balik Proses Belajar Mengajar menggunakan kuesioner yang diajukan di akhir semester kepada mahasiswa yang mengambil matakuliah tersebut. Kebutuhan adanya segmentasi pada topik Proses Belajar Mengajar, umpan balik selain kuesioner didapatkan komentar - komentar dari media sosial.

\section{B. Penyajian Fasilitas Umum}

Segmentasi penyajian pada bagian Fasilitas Umum terbagi dari tiga bagian yaitu bagian Manajemen Gedung, Wakil Rektor 3, dan Rektor. Berdasarkan kewenangan pada Fasilitas Umum maka komentar - komentar sentimen negatif dan positif akan dilanjutkan kepada bagian di atasnya yaitu Wakil Rektor 3 dan Rektor, waktu penyajian sebenarnya dapat disesuaikan dengan kebutuhan pengguna informasi.

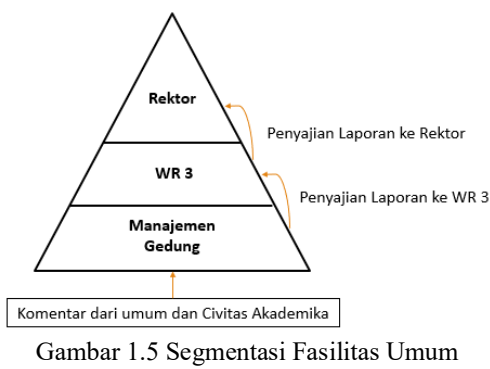

Pada penyajian informasi dari bagian Manajemen Gedung kepada Wakil Rektor akan terjadi peringkasan penyajian, yaitu laporan komentar yang dalam dua minggu, untuk sentimen positif pada Fasilitas Umum akan secara otomatis ditampilkan pada bagian Wakil Rektor 3.

Komentar - komentar mengenai Fasilitas Umum yang didapat dari masyarakat umum dan civitas akademika akan disajikan berdasarkan urutan fasilitas yang paling banyak mengandung nilai negatif dalam frekuensi yang sering muncul dengan nilai ambang batas yang dapat ditentukan seperti kejadian berulang. Manajemen Gedung akan melakukan tindakan penyelesaian terhadap komentar - komentar yang didapat, tindakan yang berhasil diselesaikan tidak akan disajikan secara langsung akan tetapi dapat diketahui oleh Wakil Rektor 3 dengan memilih detail komentar.
TABEL IV

Contoh Fasilitas Umum Manajemen GedunG

\begin{tabular}{|c|c|c|c|c|}
\hline Fasilitas & Komentar & Lokasi & Waktu & Sentimen \\
\hline Toilet & Komentar 1 & Lokasi & Tanggal \& Jam & Positif / Negatif \\
\hline Mushola & Komentar 1 & Lokasi & Tanggal \& Jam & Positif / Negatif \\
\hline Parkir & Komentar 1 & Lokasi & Tanggal \& Jam & Positif / Negatif \\
\hline Kantin & Komentar 1 & Lokasi & Tanggal \& Jam & Positif / Negatif \\
\hline $\begin{array}{c}\text { Tempat } \\
\text { Sampah }\end{array}$ & Komentar 1 & Lokasi & Tanggal \& Jam & Positif / Negatif \\
\hline Lift & Komentar 1 & Lokasi & Tanggal \& Jam & Positif / Negatif \\
\hline $\begin{array}{c}\text { Ruang } \\
\text { Rapat }\end{array}$ & Komentar 1 & Lokasi & Tanggal \& Jam & Positif / Negatif \\
\hline
\end{tabular}

Dari hasil Tabel Fasilitas Umum Manajemen Gedung sentimen - sentimen akan dijumlahkan sesuai dengan fasilitas yang ada. Urutan penyajian dari jumlah sentimen yang paling banyak mengandung sentimen negatif pada pada suatu fasilitas. Penyajian informasi akan dilaporkan setiap dua minggu kepada Wakil Rektor 3, waktu penyajian sebenarnya dapat disesuaikan dengan kebutuhan pengguna informasi.

TABEL V

CONTOH WAKIL REKTOR 3

\begin{tabular}{|c|c|c|c|c|}
\hline No & Fasilitas & Negatif & Positif & Periode \\
\hline 1 & Toilet & Jumlah Negatif & Jumlah Positif & \multirow{3}{*}{$\begin{array}{l}2 \text { Minggu } \\
\text { Pertama }\end{array}$} \\
\hline 2 & Ruang Kelas & Jumlah Negatif & Jumlah Positif & \\
\hline 3 & Laboratorium & Jumlah Negatif & Jumlah Positif & \\
\hline \multicolumn{5}{|c|}{ Lihat Lebih } \\
\hline 4 & Mushola & Jumlah Negatif & Jumlah Positif & \multirow{11}{*}{$\begin{array}{l}2 \text { Minggu } \\
\text { Pertama }\end{array}$} \\
\hline 5 & Parkir & Jumlah Negatif & Jumlah Positif & \\
\hline 6 & Kantin & Jumlah Negatif & Jumlah Positif & \\
\hline 7 & Tempat Sampah & Jumlah Negatif & Jumlah Positif & \\
\hline 8 & Lift & Jumlah Negatif & Jumlah Positif & \\
\hline 9 & Ruang Rapat & Jumlah Negatif & Jumlah Positif & \\
\hline 10 & Perpustakaan & Jumlah Negatif & Jumlah Positif & \\
\hline 11 & LCD Proyektor & Jumlah Negatif & Jumlah Positif & \\
\hline 12 & Meja & Jumlah Negatif & Jumlah Positif & \\
\hline 13 & Kursi & Jumlah Negatif & Jumlah Positif & \\
\hline 14 & Komputer & Jumlah Negatif & Jumlah Positif & \\
\hline
\end{tabular}

Pada penyajian Wakil Rektor 3, informasi yang laporan akan diringkas menjadi 3 fasilitas dengan jumlah negatif terbanyak. Untuk melihat detail sentimen negatif atau positif Wakil Rektor 3 dapat memilih kolom jumlah sentimen pada setiap fasilitas yang tersajikan, penyajian detail jumlah sentimen akan sama seperti tabel Contoh Fasilitas Umum Manajemen Gedung. Periode laporan dari Manajemen Gedung ke Wakil Rektor 3 setiap dua minggu, periode waktu dapat dipilih untuk penyajian informasi.

Dari hasil laporan Fasilitas Umum pada bagian Wakil Rektor 3 akan disajikan kepada Rektor menggunakan grafik, grafik tersebut akan menampilkan 2 fasilitas ternegatif yang terakumulasi setiap bulannya. Hal ini dilakukan untuk tidak terjadinya penyajian informasi yang berlebih, informasi yang sesuai kemampuan kognitif penerima informasi. 


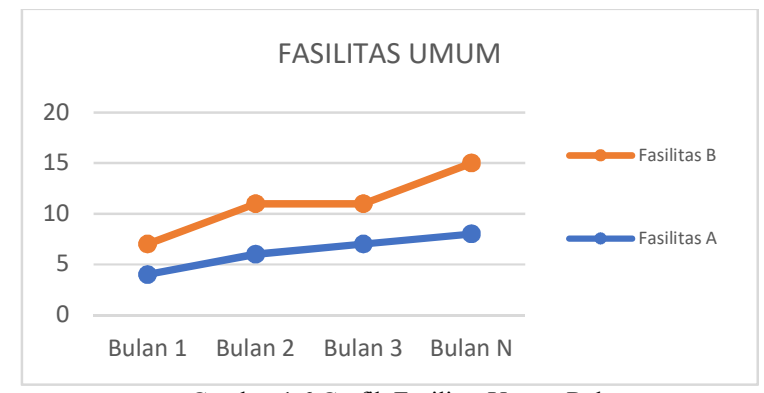

Gambar 1.6 Grafik Fasilitas Umum Rektor

Selain penyajian dalam bentuk grafik, rektor akan disajikan ringkasan dalam bentuk tabel yang berfungsi apabila Rektor membutuhkan informasi yang lebih detail terkait dengan Fasilitas Umum.

\section{TABEL VI}

Contoh Fasilitas Umum Manajemen Gedung

\begin{tabular}{|c|c|c|c|c|}
\hline \multicolumn{5}{|c|}{ Fasilitas Umum } \\
\hline No & Bulan & Negatif & Positif & Fasilitas \\
\hline 1 & Bulan 1 & Jumlah Negatif & Jumlah Positif & Fasilitas A \\
\hline 2 & Bulan 2 & Jumlah Negatif & Jumlah Positif & Fasilitas A \\
\hline 3 & Bulan 3 & Jumlah Negatif & Jumlah Positif & Fasilitas B \\
\hline 4 & Bulan 4 & Jumlah Negatif & Jumlah Positif & Fasilitas C \\
\hline 5 & Bulan n & Jumlah Negatif & Jumlah Positif & Fasilitas n \\
\hline
\end{tabular}

Tabel Ringkasan Rektor dapat mengetahui fasilitas fasilitas yang dikomentari negatif pada setiap bulannya, pada tabel tersebut dapat dilihat detail dengan memilih kolom bulan, jika dipilih maka akan tersajikan tabel seperti tabel Wakil Rektor 3.

\section{Penyajian Fasilitas Akademik}

Segmentasi penyajian pada bagian Fasilitas Akademik terbagi dari tiga bagian yaitu bagian Bagian Perlengkapan, Wakil Rektor 2, dan Rektor. Berdasarkan kewenangan pada Fasilitas Akademik maka komentar - komentar sentimen negatif dan positif akan dilanjutkan kepada bagian di atasnya yaitu Wakil Rektor 2 dan Rektor.

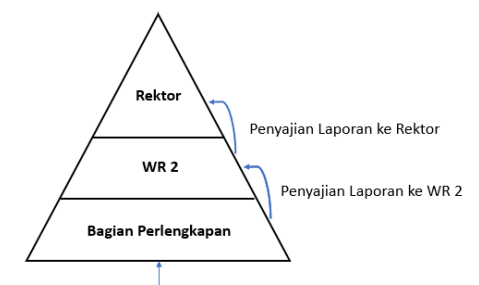

Komentar dari Mahasiswa dan Penunjang Akademik

Gambar 1.7 Segmentasi Fasilitas Akademik

Pada penyajian informasi dari Bagian Perlengkapan kepada Wakil Rektor 2 akan terjadi peringkasan penyajian, yaitu laporan komentar dalam dua minggu, untuk sentimen positif pada Fasilitas Akademik akan secara otomatis ditampilkan pada bagian Wakil Rektor 2 .

Komentar - komentar mengenai Fasilitas Akademik yang didapat dari mahasiswa dan penunjang akademik seperti Dosen, Bagian Administrasi, dan non Administrasi akan disajikan berdasarkan urutan fasilitas yang paling banyak mengandung nilai negatif dalam frekuensi yang sering muncul dengan nilai ambang batas yang dapat ditentukan seperti kejadian berulang. Bagian Perlengkapan akan melakukan tindakan penyelesaian terhadap komentar - komentar yang didapat, tindakan yang berhasil diselesaikan tidak akan disajikan secara langsung akan tetapi dapat diketahui oleh Wakil Rektor 2 dengan memilih detail komentar.

TABEL VII

CONTOH FASILITAS UMUM MANAJEMEN GEDUNG

\begin{tabular}{|c|c|c|c|c|}
\hline Fasilitas & Komentar & Lokasi & Waktu & Sentimen \\
\hline \multirow{5}{*}{ Ruang Kelas } & Komentar 1 & Lokasi & $\begin{array}{c}\text { Tanggal } \\
\text { \& Jam }\end{array}$ & Positif / Negatif \\
\hline & Komentar 2 & Lokasi & $\begin{array}{c}\text { Tanggal } \\
\text { \& Jam }\end{array}$ & Positif / Negatif \\
\hline & Komentar 3 & Lokasi & $\begin{array}{c}\text { Tanggal } \\
\text { \& Jam }\end{array}$ & Positif / Negatif \\
\hline & Komentar 4 & Lokasi & $\begin{array}{c}\text { Tanggal } \\
\& \text { Jam }\end{array}$ & Positif / Negatif \\
\hline & Komentar 5 & Lokasi & $\begin{array}{c}\text { Tanggal } \\
\text { \& Jam }\end{array}$ & Positif/ Negatif \\
\hline Komputer & Komentar 1 & Lokasi & $\begin{array}{c}\text { Tanggal } \\
\text { \& Jam }\end{array}$ & Positif / Negatif \\
\hline \multirow{2}{*}{$\begin{array}{l}\text { Laboratorium } \\
\text { Perpustakaan }\end{array}$} & Komentar 1 & Lokasi & $\begin{array}{c}\text { Tanggal } \\
\text { \& Jam }\end{array}$ & Positif / Negatif \\
\hline & Komentar 2 & Lokasi & $\begin{array}{c}\text { Tanggal } \\
\& \text { Jam }\end{array}$ & Positif / Negatif \\
\hline LCD Proyector & Komentar 1 & Lokasi & $\begin{array}{c}\text { Tanggal } \\
\& \text { Jam }\end{array}$ & Positif / Negatif \\
\hline Meja / Kursi & Komentar 1 & Lokasi & $\begin{array}{c}\text { Tanggal } \\
\text { \& Jam }\end{array}$ & Positif / Negatif \\
\hline
\end{tabular}

Dari hasil Tabel Fasilitas Akademik Bagian Perlengkapan, Fasilitas Akademik sentimen - sentimen akan dijumlahkan sesuai dengan fasilitas yang ada. Urutan penyajian dari jumlah sentimen yang paling banyak mengandung sentimen negatif pada pada suatu fasilitas. Penyajian informasi akan dilaporkan setiap dua minggu kepada Wakil Rektor 2, waktu penyajian sebenarnya dapat disesuaikan dengan kebutuhan pengguna informasi.

TABEL VIII

CONTOH Fasilitas UMUM MANAJEMEN GEDUNG

\begin{tabular}{|c|c|c|c|c|}
\hline No & Fasilitas & Negatif & Positif & Periode \\
\hline 1 & Ruang Kelas & Jumlah Negatif & Jumlah Positif & \multirow{2}{*}{$\begin{array}{c}\text { Minggu } \\
\text { Pertama }\end{array}$} \\
\hline 2 & Komputer & Jumlah Negatif & Jumlah Positif & \\
\hline 3 & Laboratorium & Jumlah Negatif & Jumlah Positif & \\
\hline \multicolumn{5}{|c|}{ Lihat Lebih } \\
\hline 4 & Perpustakaan & Jumlah Negatif & Jumlah Positif & \multirow{2}{*}{$\begin{array}{c}\text { 2 Minggu } \\
\text { Pertama }\end{array}$} \\
\hline 5 & LCD Proyector & Jumlah Negatif & Jumlah Positif & \\
\hline 6 & Meja / Kursi & Jumlah Negatif & Jumlah Positif & \\
\end{tabular}

Pada penyajian Wakil Rektor 2, informasi yang laporan akan diringkas menjadi 3 fasilitas dengan jumlah negatif terbanyak. Untuk melihat detail sentimen negatif atau positif Wakil Rektor 2 dapat memilih kolom jumlah sentimen pada setiap fasilitas yang tersajikan, penyajian detail jumlah sentimen akan sama seperti tabel Contoh Fasilitas Akademik Bagian Perlengkapan

Dari hasil laporan Fasilitas Akademik pada bagian Wakil Rektor 2 akan disajikan kepada Rektor menggunakan grafik, grafik tersebut akan menampilkan 2 fasilitas ternegatif yang 
terakumulasi setiap bulannya. Hal ini dilakukan untuk tidak terjadinya penyajian informasi yang berlebih, informasi yang sesuai kemampuan kognitif penerima informasi.

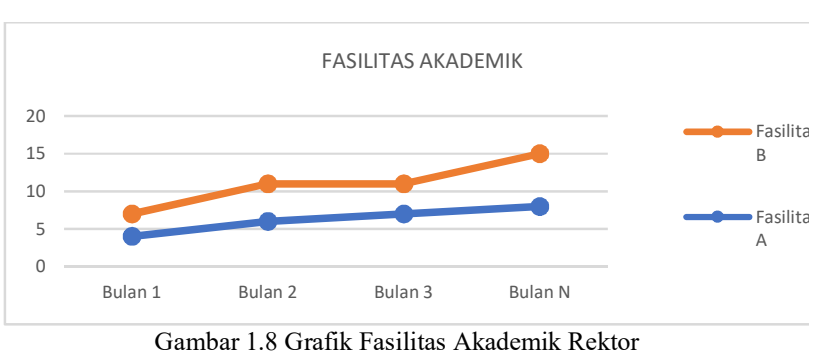

Selain penyajian dalam bentuk grafik, rektor akan disajikan ringkasan dalam bentuk tabel yang berfungsi apabila Rektor membutuhkan informasi yang lebih detail terkait dengan Fasilitas Akademik.

TABEL IX

CONTOH RINGKASAN FASILITAS AKADEMIK REKTOR

\begin{tabular}{|c|c|c|c|c|}
\hline \multicolumn{5}{|c|}{ Fasilitas Akademik } \\
\hline No & Bulan & Fasilitas & Negatif & Positif \\
\hline 1 & Bulan 1 & Fasilitas A & Jumlah Negatif & Jumlah Positif \\
\hline 2 & Bulan 2 & Fasilitas A & Jumlah Negatif & Jumlah Positif \\
\hline 3 & Bulan 3 & Fasilitas B & Jumlah Negatif & Jumlah Positif \\
\hline 4 & Bulan 4 & Fasilitas C & Jumlah Negatif & Jumlah Positif \\
\hline 5 & Bulan N & Fasilitas N & Jumlah Negatif & Jumlah Positif \\
\hline
\end{tabular}

\section{Penyajian Proses Belajar dan Belajar}

Komentar - komentar mengenai Proser Belajar dan Mengajar yang didapat dari mahasiswa akan disajikan berdasarkan urutan komentar yang paling banyak mengandung nilai negatif dalam frekuensi yang sering muncul dengan nilai ambang batas yang dapat ditentukan seperti kejadian berulang. Dosen akan melakukan tindakan penyelesaian terhadap komentar - komentar yang didapat, tindakan yang berhasil diselesaikan tidak akan disajikan secara langsung akan tetapi dapat diketahui oleh Kaprodi dengan memilih detail komentar. Komentar - komentar dari mahasiswa yang telah melakukan login akan disajikan kepada setiap bagian - bagian dosen terkait.

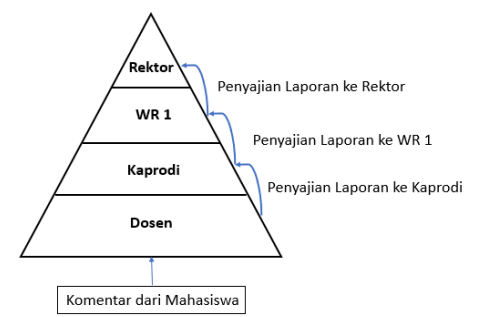

Gambar 1.9 Segmentasi Proses Belajar dan Mengajar

Komentar mahasiswa mengenai Proses Belajar dan Mengajar dapat terbagi - bagi sesuai dengan topik pembahasan dan dosen terkait seperti contoh topik kedisiplinan terhadap dosen tertentu, dari komentar - komentar yang ada akan ditujukan kepada dosen - dosen yang sesuai.
TABEL X

Contoh Belajar Mengajar Dosen - Dosen Terkait

\begin{tabular}{|c|c|c|c|c|}
\hline No & Topik & Komentar & Waktu & Sentimen \\
\hline 1 & Topik A & Komentar & Tanggal \& Jam & Positif/ Negatif \\
\hline 2 & Topik B & Komentar & Tanggal \& Jam & Positif/ Negatif \\
\hline 3 & Topik C & Komentar & Tanggal \& Jam & Positif / Negatif \\
\hline 4 & Topik N & Komentar & Tanggal \& Jam & Positif / Negatif \\
\hline
\end{tabular}

Di dalam aturan Data Segmentasi Informasi, Kaprodi dapat mengetahui mengenai informasi - informasi dosen pada jenjang di bawahnya. Dari hasil tabel Belajar dan Mengajar Dosen - Dosen Terkait akan disajikan kepada Kaprodi dengan urutan penyajian dari jumlah sentimen dosen yang paling banyak mengandung sentimen negatif pada pada suatu jurusan.

TABEL XI

CONTOH Belajar Mengajar KaPRodi

\begin{tabular}{|c|c|c|c|c|}
\hline $\begin{array}{l}\mathrm{N} \\
\mathrm{o}\end{array}$ & Dosen & Negatif & Positif & Periode \\
\hline 1 & Dosen A & Jumlah Negatif & Jumlah Positif & \multirow{3}{*}{ Minggu Pertama } \\
\hline 2 & Dosen B & Jumlah Negatif & Jumlah Positif & \\
\hline 3 & Dosen $\mathrm{C}$ & Jumlah Negatif & Jumlah Positif & \\
\hline \multicolumn{5}{|c|}{ Lihat Lebih } \\
\hline 4 & Dosen D & Jumlah Negatif & Jumlah Positif & \multirow{3}{*}{ Minggu Pertama } \\
\hline 5 & Dosen E & Jumlah Negatif & Jumlah Positif & \\
\hline 6 & Dosen F & Jumlah Negatif & Jumlah Positif & \\
\hline
\end{tabular}

Pada penyajian Kaprodi, informasi yang laporan akan diringkas menjadi 3 dosen dengan jumlah negatif terbanyak. Untuk melihat detail sentimen negatif atau positif Kaprodi dapat memilih kolom jumlah sentimen pada setiap dosen yang tersajikan, penyajian detail jumlah sentimen akan sama seperti tabel Belajar dan Mengajar Dosen - Dosen Terkait

Di dalam aturan Data Segmentasi Informasi, Wakil Rektor 1 dapat mengetahui mengenai informasi - informasi Kaprodi pada jenjang di bawahnya. Dari hasil Tabel Belajar dan Mengajar Kaprodi akan disajikan kepada Wakil Rektor 1 dengan urutan penyajian dari jumlah sentimen Kaprodi yang paling banyak mengandung sentimen negatif pada pada suatu fakultas. Penyajian informasi akan dilaporkan setiap dua minggu kepada Wakil Rektor 1, waktu penyajian sebenarnya dapat disesuaikan dengan kebutuhan pengguna informasi.

TABEL XII

CONTOH Belajar Mengajar WaKil ReKTOR 1

\begin{tabular}{|c|c|c|c|c|}
\hline No & Kaprodi & Negatif & Positif & Periode \\
\hline 1 & $\begin{array}{c}\text { Kaprodi } \\
\text { A }\end{array}$ & Jumlah Negatif & Jumlah Positif & \multirow{3}{*}{ Minggu Pertama } \\
\hline 2 & $\begin{array}{c}\text { Kaprodi } \\
\text { B }\end{array}$ & Jumlah Negatif & Jumlah Positif & \\
\hline 3 & $\begin{array}{l}\text { Kaprodi } \\
\text { C }\end{array}$ & Jumlah Negatif & Jumlah Positif & \\
\hline \multicolumn{5}{|c|}{ Lihat Lebih } \\
\hline 4 & $\begin{array}{c}\text { Kaprodi } \\
\text { D }\end{array}$ & Jumlah Negatif & Jumlah Positif & \multirow{3}{*}{ Minggu Pertama } \\
\hline 5 & $\begin{array}{c}\text { Kaprodi } \\
\text { E }\end{array}$ & Jumlah Negatif & Jumlah Positif & \\
\hline 6 & $\begin{array}{c}\text { Kaprodi } \\
\text { F }\end{array}$ & Jumlah Negatif & Jumlah Positif & \\
\hline
\end{tabular}


Pada penyajian Wakil Rektor 1, informasi yang laporan akan diringkas menjadi 3 Kaprodi dengan jumlah negatif terbanyak. Untuk melihat detail sentimen negatif atau positif Wakil Rektor 1 dapat memilih kolom jumlah sentimen pada setiap Kaprodi yang tersajikan, penyajian detail jumlah sentimen akan sama seperti tabel Belajar dan Mengajar Kaprodi.

Dari hasil laporan Proses Belajar dan Mengajar pada bagian Wakil Rektor 1 akan disajikan kepada Rektor menggunakan grafik, grafik tersebut akan menampilkan 2 jurusan ternegatif yang terakumulasi setiap bulannya. Hal ini dilakukan untuk tidak terjadinya penyajian informasi yang berlebih, informasi yang sesuai kemampuan kognitif penerima informasi.

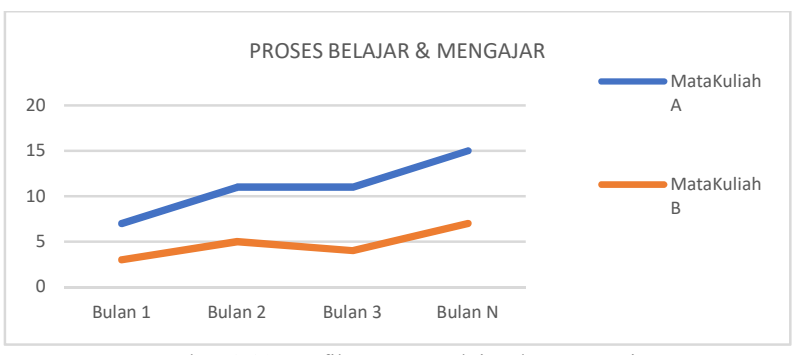

Gambar 1.10 Grafik Proses Belajar dan Mengajar

Selain penyajian dalam bentuk grafik, rektor akan disajikan ringkasan dalam bentuk tabel yang berfungsi apabila Rektor membutuhkan informasi yang lebih detail terkait dengan Proses Belajar dan Mengajar pada jurusan.

TABEL XIII

CONTOH RingKasan BElajar \& MENGajar REKTOR

\begin{tabular}{|c|c|c|c|c|}
\hline \multicolumn{5}{|c|}{ Fasilitas Akademik } \\
\hline No & Bulan & Jurusan & Negatif & Positif \\
\hline 1 & $\begin{array}{c}\text { Bulan } \\
1\end{array}$ & Jurusan A & Jumlah Negatif & Jumlah Positif \\
\hline 2 & $\begin{array}{c}\text { Bulan } \\
2\end{array}$ & Jurusan B & Jumlah Negatif & Jumlah Positif \\
\hline 3 & $\begin{array}{c}\text { Bulan } \\
3\end{array}$ & Jurusan C & Jumlah Negatif & Jumlah Positif \\
\hline 5 & $\begin{array}{c}\text { Bulan } \\
4\end{array}$ & Jurusan D & Jumlah Negatif & Jumlah Positif \\
\hline
\end{tabular}

\section{E. Penyajian Segmentasi Lainya}

Pada setiap kelompok topik komentar yang terdiri dari Fasilitas Umum, Fasilitas Akademik, Proses Belajar dan Mengajar sudah terdapat daftar fasilitas - fasilitas dan topik topiknya. Untuk menangani komentar di luar daftar yang ada, maka komentar - komentar yang ada pada media sosial akan dilakukan teknik Sentimen Analisis dan Fitur Analisis yang sudah ada, hasil fitur - fitur yang sudah didapatkan dengan teknik ini akan disegmentasikan oleh bagian humas kepada setiap kelompok topik komentar.

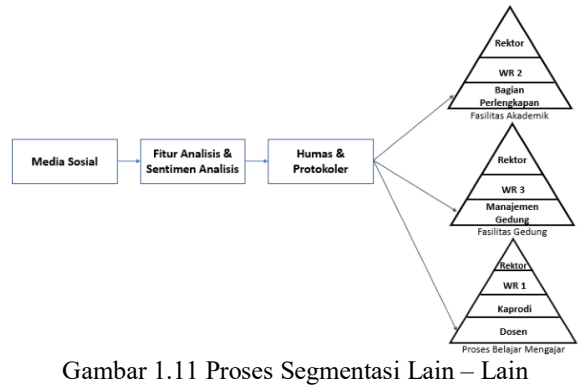

Komentar - komentar yang didapat dari media sosial akan dilakukan proses Sentimen Analisis, yaitu proses menilai sebuah komentar yang memiliki sentimen negatif atau positif, setalah proses Sentimen Analisis komentar tersebut akan diproses menggunakan Fitur Analis, yaitu proses untuk mengetahui topik / fitur pembahasan di dalam sebuah komentar. Hasil proses dari Sentimen Analisis dan Fitur Analisis akan diberikan kepada bagian Humas \& Protokoler untuk pendistribusian kepada pihak - pihak yang berkepentingan sesuai dengan komentar yang didapat.

\section{F. Penyajian Rektor Keseluruhan}

Dari hasil Kelompok topik komentar dari Tabel Fasilitas Umum Wakil Rektor 3, Fasilitas Akademik, Wakil Rektor 2, dan Proses Belajar dan Mengajar Wakil Rektor 1 akan disajikan bahasan negatif dari ketiga kelompok dalam bentuk grafik, 5 komentar terburuk akan disajikan, laporan komentar yang berhasil diselesaikan tidak langsung disajikan akan tetapi dapat dilihat pada informasi detail pada setiap bagian. Penyajian informasi akan dilaporkan setiap bulannya dengan rentang waktu satu tahun kepada Rektor, waktu penyajian sebenarnya dapat disesuaikan dengan kebutuhan pengguna informasi.

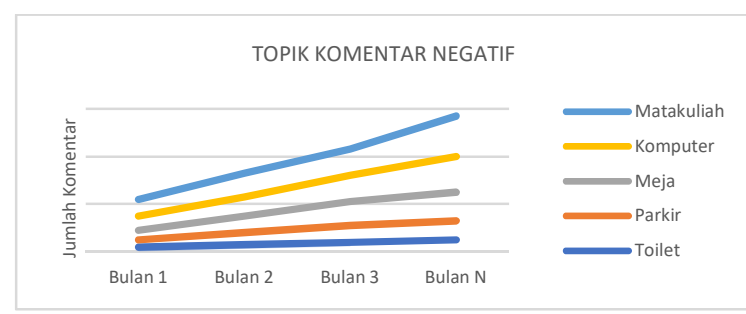

Gambar 1.12 Kelompok Topik Komentar Negatif Rektor

Dengan Memilih bagian Matakuliah maka penyajian detail informasi yang didapatkan seperti gambar grafik Proses Belajar dan Mengajar Rektor, di dalam grafik ini jika Rektor membutuhkan informasi lebih detail maka dapat memilih daftar Matakuliah dan kemudian akan tersajikan informasi seperti tabel Wakil Rektor 1 dan juga dapat melihat detail informasi Dekan, Kaprodi. 


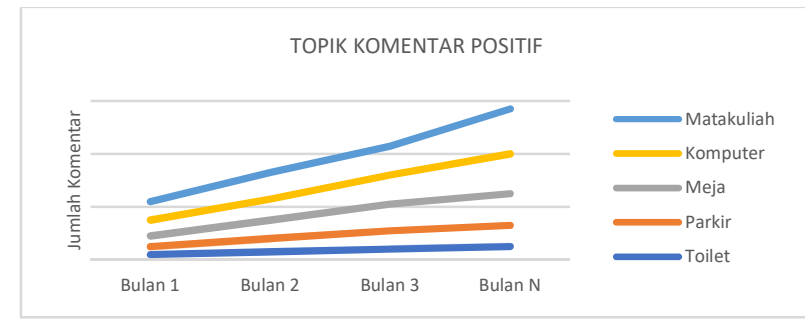

Gambar 1.13 Kelompok Topik Komentar Positif Rektor

Detail tindakan laporan yang yang berhasil dilakukan pada setiap jenjang bagian pelaksana akan disajikan dalam bentuk grafik dengan jumlah laporan negatif dan jumlah laporan yang berhasil diselesaikan pada setiap jenjang, contoh grafik penyelesaian masalah dapat dilihat pada gambar berikut.

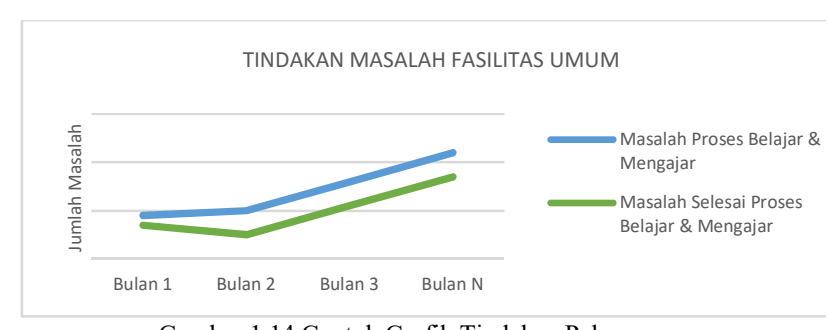

Gambar 1.14 Contoh Grafik Tindakan Pelaporan

Grafik tindakan pelaporan akan menyajikan jumlah keseluruhan komentar negatif dan jumlah hasil tindakan yang telah diselesaikan setiap bulannya pada bagian pelaksana. Dengan grafik tersebut dapat digunakan juga untuk melihat kinerja pada setiap bagian.

\section{KESIMPULAN}

Gabungan antara Piramida Hirarki, Piramida Sistem Informasi, dan Cognitive Load dapat menyajikan informasi dengan konteks dan jumlah yang tepat sesuai dengan jenjang yang ada pada Universitas Komputer Indonesia.

\section{UCAPAN TERIMA KASIH}

Segala puji bagi Allah SWT yang telah memberikan penulis kemudahan sehingga tesis yang berjudul "TEKNIK MENYAJIKAN DATA HASIL SENTIMEN ANALISIS BERDASARKAN STRUKTUR ORGANISASI PADA DOMAIN PERGURUAN TINGGI" dapat terselesaikan dengan tepat waktu.

\section{REFERENSI}

[1] R. Humphries, "CHAPTER 1 Review of some mathematical and physical subjects," vol. 0, no. Snati, pp. 1-53, 1968.

[2] I. F. Rozi, S. H. Pramono, and E. A. Dahlan, "Implementasi Opinion Mining ( Analisis Sentimen ) untuk Ekstraksi Data Opini Publik pada Perguruan Tinggi," J. EECCIS (Electrics, Electron. Commun. Control. Informatics, Syst., vol. 6, no. 1, pp. 37-43, 2012.

[3] M. Zeleny, "Integrated Knowledge Management," Int. J. Inf. Syst. Soc. Chang., vol. 4, no. 4, pp. 62-78, 2013.

[4] T. Mihovsky and G. Naydenova, "Comparative study on czech cultivars of red clover (Trifolium Pratense L.) in the conditions of the central northern Bulgaria," Bulg. J. Agric. Sci., vol. 23, no. 5, pp. 739-742, 2017.

[5] J. Rowley, "The wisdom hierarchy: Representations of the DIKW hierarchy," J. Inf. Sci., vol. 33, no. 2, pp. 163-180, 2007.

[6] R. Ackoff, "MNeri 20130124."

[7] H. J. Onsrud, "Chapter 9 Tragedy of the Information Commons," Mod. Cartogr. Ser., vol. 3, no. C, pp. 141-158, 1998.

[8] K. Dasar, "M a n a jem e n s i st e m in for $\mathrm{m}$ as i da n t e $\mathrm{kn}$ o lo g i i n fo r m as i," Manejemen Sist. Inf. dan Teknol. Inf., vol. 276, no. Supply Dari Informasi, p. 10, 2000.

[9] J. M. Bryson, "What to do when stakeholders matter: Stakeholder Identificatixon and analysis techniques," Public Manag. Rev., vol. 6, no. 1 , pp. 21-53, 2004

[10] I. M. A. Mahadi, "Analisis Stakeholder Mapping: Studi Kasus Pada Professional Products Division L ' Oréal Indonesia Periode Januari Juni 2013," no. 1999, pp. 1-19, 2013.

[11] L. C. Ballejos, S. M. Gonnet, and J. M. Montagna, "A stakeholder model for interorganizational information systems," Lect. Notes Comput. Sci. (including Subser. Lect. Notes Artif. Intell. Lect. Notes Bioinformatics), vol. 5025 LNCS, pp. 73-87, 2008.

[12] F. Andriyanto and H. Purnaweni, "Analisis Stakeholders Dalam Formulasi Kebijakan Kota Layak Anak Di Kota Semarang," J. Public Policy Manag. Rev., vol. 6 (2), 2017.

[13] S. Navigation and N. S. Route, "Pengaruh Sistem Pengukuran Kinerja Dan Kejelasan Peran Terhadap Kinerja Karyawan,” no. 2005.

[14] D. W. I. Putri, I. Kompetensi, P. Pemimpin, P. Tinggi, D. I. Tingkat, and U. Andalas, "TINGGI DI TINGKAT JURUSAN ( Studi pada Universitas Andalas )," 2015.

[15] B. Cobit, "Irfan AP," no. 20, pp. 1-6, 2014.

[16] F. Hasan, "Kepentingan Stakeholders Terhadap Perusahaan," Sabbath Recorder, 2014. [Online]. Available: https://fakhrurrojihasan.wordpress.com/2014/03/09/apa-sajakepentingan-stakeholders-terhadap-perusahaan-anda/.

[17] Endah Retnowati, "Keterbatasan Memori dan Implikasinya dalam Mendesain Metode Pembelajaran Matematika," pp. 1-13.

[18] B. Yohanes, Subanji, and Sisworo, "Beban Kognitif Siswa Dalam Pembelajaran," J. Pendidik. Teor. Penelit. dan Pengemb., vol. 1, no. 2, pp. 187-195, 2016.

[19] Bachtiar, A. M., Dharmayanti, D., \& Imammulloh, M. (2018, August). Data Visualization of Environmental Factors in Poultry Farm. In IOP Conference Series: Materials Science and Engineering (Vol. 407, No. 1, p. 012120). IOP Publishing. 